\title{
KONFLIKT LOAJALIT. POSTOJE SLOVENSKÉHO EPISKOPÁTU V PROCESU SLOŽITÉHO PROVÁDĚNÍ MODU VIVENDI 1928-1935
}

\author{
EVA H A J D I N O V Á
}

\begin{abstract}
HAJDINOVÁ, Eva. Conflict of Loyalties. Attitudes of the Slovak Episcopate During the Complicated Negotiation of the Modus Vivendi Agreement 1928-1935. Historický časopis, 2019, 67, 1, pp. 53-81, Bratislava. Within the framework of conflicts of loyalties, the author analyses the variable attitudes of the Slovak episcopate between 1928 and 1934 towards the complex negotiations regarding the application of the Modus vivendi agreement. In the unstable post-war social, political and economic climate, the Czechoslovak state imposed a sequester on the Slovak ecclesiastical estates. This progressively caused dissatisfaction, scepticism, and distrust amongst Slovak church dignitaries; leading to severe complaints to the Vatican against the Czechoslovak government by representatives of the Catholic Church in Slovakia, led by the Bishop of Spiš, Msgr. Ján Vojtaššák. The conflict within the state culminated in secret negotiations that took place in December 1932 and June 1934 between the Slovak bishops and the Archbishop of Esztergom Jusztinián Serédi.
\end{abstract}

Keywords: Modus vivendi. Slovak episcopate. Diocesan boundaries. Relations between Czechoslovakia and the Holy See. Administration of Church estates. Loyalty.

DOI: https://doi.org/10.31577/histcaso.2019.67.1.3

Od počátku vzniku Československa byly nastoleny nesnadné otázky týkající se postoje státu ke katolické církvi a zároveň problém postavení Slovenska a Podkarpatské Rusi v rámci nového státu. Katolická církev měla ovšem, na rozdíl od Čech, na Slovensku vlivnější postavení. V porevolučním období Češi Slovákům direktivně poskytli kulturně-politickou a společenskou pomoc a spolupráci, jejíž nedílnou součástí byla snaha zachování vlivu státu v římsko-katolické církvi. Toto úsilí způsobilo četné problémy mezi slovenskými církevními hodnostáři a státem. Některé přetrvaly jako dlouholeté neshody církevních představitelů vưči centrální vládě.

Vývoj vztahu Československa vǔči katolické církvi a věřícím s velkou pozorností a nemalými obavami sledoval Svatý stolec. K tématu tohoto procesu vyšlo v posledních letech několik studií. Jejich závěry mimo jiné ukazují, že slovenští katolíci nebyli připraveni dostatečně pohotově reagovat na sekularizační změny, které po roce 1918 nastaly. Tento text se zaměří na poněkud odlišný problém, 
a to na stanoviska slovenského vyššího kléru k provádění dohody o modu vivendi, který ČSR na sklonku roku 1927 uzavřelo se Svatým stolcem. Po roce 1918 došlo na celém území Československa k obměně vysoké církevní hierarchie, která neměla jen generační, ale předně národnostní a sociální rozměr. V odborné literatuře se často objevuje interpretace ukazující mnohé slovenské duchovní, včetně nejvyšší církevní hierarchie jako aktivní zastánce slovenské autonomistické opozice. ${ }^{1}$ Vyšší klérus stejně jako obyčejní věřící a kněží často vnímal pražská centrální rozhodnutí jako diktát ohrožující prosperitu církve. Stát měl, naopak, mnoho výhrad vůči inherenci církevních hodnostářů do svých pravomocí. Jako protivládní akt chápali mnozí členové tehdejší celonárodní koalice a zejména sociálnědemokratický tisk vydání společného pastýřského listu slovenským episkopátem na sklonku listopadu 1924, který se vymezoval vůči nekřest’anským pokrokářským spolkům, včetně Sokola, kritizoval a nepřímo odsuzoval celkovou náboženskou situaci v republice. ${ }^{2}$ Byly dokonce zvažovány postihy proti biskupům a kněžím šiŕícím tento list, ve smyslu přestupku pobuřování, překročení volebního zákona či dokonce zákona o ochraně republiky. Nakonec se k nim ovšem nepřistoupilo.

Převrat podzimu 1918 postavil církve před nové otázky a jednou ze zásadních byla loajalita k novému státu. ${ }^{3}$ Jednalo se o horizontální typ loajality, která měla duchovní vést k pocitu sounáležitosti s československou státotvornou ideou. Nezřídka se ovšem dostávala do konfliktu s loajalitou vertikální, jež hodnostáře zavazovala $\mathrm{k}$ poslušnosti vůči jejich církevním nadřízeným. Za výlučnou loajalitu k církvi, a předně k římské kurii, očekávali duchovní ochranu před skutečným nebo fiktivním ohrožením svých výsad. Neochota či přímo odmítání „politické“ poslušnosti republice pak jednoznačně souvisely s autoritářským sebepojetím duchovních jakožto společenského stavu, který se stále častěji cítil odstaven od možnosti iniciovat a ovlivnit společenské změny. ${ }^{4}$

1 Např́iklad PEHR, Michal - ŠEBEK, Jaroslav. Československo a Svatý stolec. Od neprátelství ke spolupráci (1918-1928). I. Úvodní studie. Praha: Masarykův ústav AV ČR, 2012, s. 125 nn. ISBN 9788086495736; BARTLOVÁAlena. Andrej Hlinka. Bratislava: Obzor, 1997, s. 89-106. ISBN 8021502045 či starší práce KRAMER, Juraj. Iredenta a separatizmus v slovenskej politike. Bratislava: Slovenské vydavatel'stvo politickej literatúry, 1957. Velká část církevní hierarchie se nicméně nadále podle hesla „,nemůžeš sloužit dvěma pánům“ snažila zamezit angažovanosti slovenských kleriků v politice.

2 PEHR - ŠEBEK, ref. 1, s. 129-133. List byl ovšem primárně namířen proti aktivitám socialistů a komunistů. K tomu nedávno např. ŠTOFANÍK, Jakub. Medzi križom a kladivom: recepcia sociálneho myslenia v katolíckej cirkvi v prvej polovici 20. storočia. Praha: Filozofická fakulta UK, 2017, s. 122-126. ISBN 9788073087197.

3 SCHULZE WESSEL, Martin (Hg.). Loyalitäten in der Tschechoslowakischen Republik 1918-1938. Politische, nationale und kulturelle Zugehörigkeiten. München: Collegium Carolinum, 2004. ISBN 3486575872.

4 FASORA, Lukáš et al. Kněžské identity v českých zemích. 1820-1938. Praha: NLN, 2017, 
Analytický koncept konfliktu loajalit nabízí užitečný nástroj komplexně a nezaujatě interpretovat názorová stanoviska a kroky slovenského episkopátu. Zánik starých monarchií umocnil tradiční rozporuplný postoj církve v otázce poslušnosti vůči církevní versus sekulární hierarchii. V ideálním, ovšem těžce dosažitelném případě, měli duchovní prokazovat loajalitu jak nejvyšším představitelům katolické církve, tak také vysokým činitelům státu, jehož se stali součástí. Tento nesnadný závazek přitom do značné míry ovlivňovaly zásahy křest’anských politických stran, předně Československá strana lidová a Slovenská strana l'udová (SL'S). ${ }^{5}$

Jakkoli se katoličtí hodnostáři na Slovensku projevovali jako nelehký aktér vyjednávání o novém uspořádání církevních poměrů v zemi, je třeba korigovat jednostranné a zjednodušené interpretace týkající se jejich protivládních a protičeských postojů. $\mathrm{V}$ čase převratu usiloval o konsolidaci církevních poměrů na Slovensku a dosažení loajality duchovních k novému státnímu útvaru ostatně sám předseda SL'S Andrej Hlinka. V roce 1923 podali slovenští biskupové u papeže stížnost na římskokatolického kněze a politika Františka Jehličku, ${ }^{6}$ jenž byl od roku 1919 výrazným stoupencem autonomistické promad'arsky orientované politiky. Obvinili jej z pokusu o rozbití státu, distancovali se od něj a žádali pro něj církevní trest. ${ }^{7}$ Postoje slovenského episkopátu vưči novému státnímu zřízení byly nicméně velmi proměnlivé v čase a mnohdy rozporuplné.

\section{Církevní a náboženské poměry v ČSR po roce 1918}

Jedním z cílů poválečného Československa bylo posílit státní suverenitu založenou na ideji tzv. čechoslovakismu. Nejprve bylo zapotřebí ustanovit a upevnit státní hranice. Bylo prritom žádoucí, aby se hranice církevních celků upravily tak, aby co nejvíce odpovídaly hranicím státu. Definováním nových diecézních

\section{s. 7-13. ISBN 9788074225673.}

5 Slovenský politický katolicismus v podobě Hlinkovy SLSS stál s výjimkou let 1927-1929 v ostré opozici vůči vládám první republiky. LETZ, Robert - MULÍK, Peter - BARTLOVÁ, Alena. Slovenská l'udová strana v dejinách 1905-1945. Martin: Matica slovenská, 2006. ISBN 8070908270.

6 Jako poslanec l’udové strany byl František W. Jehlička účastníkem českého krajinského hnutí za první světové války. Byl spoluautorem Memoranda slovenského národa a od roku 1919 působil v zahraničí, kde se zasazoval o rozchod s Čechy a návrat Slovenska pod Svatoštěpánskou korunu. Na přelomu dvacátých a třicátých let 20. století publikoval řadu jasně protičeskoslovensky a autonomisticky orientovaných brožur, které šíril v politických kruzích dohodových mocností a taktéž u Svatého stolce. Srov. soubor Jehličkovy korespondence a jeho tisků v archivu Segreteria di Stato, fondo Congregazione degli Affari Ecclesiastici Straordinari (dále S. RR. SS., f. AA. EE. SS.), fasc 27, pos 16.

7 ISTVÁN, Janek. František Jehlička and his activity in support of the Hungarian revision in Czechoslovakia in 1919-1938. In Dvacáté století, 2015, roč. 7, č. 2, s. 43-55. ISSN 23366656. 
hranic mělo dojít $\mathrm{k}$ vyloučení přetrvávání jurisdikce biskupů a řeholních představitelů sídlících mimo ČSR na československém území. Tito převážně mad'arskojazyční hodnostáři měli být na Slovensku nahrazeni česky a slovensky hovoř́ícími duchovními, loajálními ke státu a jeho centralistické politice. ${ }^{8}$ Nesnadný a zdlouhavý proces obsazování slovenských biskupských stolců je v literatuře posledních let dobře známým a zpracovaným tématem. ${ }^{9}$ Státní činitelé se snažili, aby byli noví ordináři vybráni z řad provládně smýšlejících kněží, kteří měli do budoucna garantovat vzájemnou spolupráci, a v podstatě umenšovat vliv SLS. ${ }^{10}$ Svatý stolec zaujal vůči vývoji na Slovensku oficiálně nestranné stanovisko bez zjevných náznaků podpory slovenské autonomie. Skrze svůj nárok definitivního výběru a nominace biskupů však ve skutečnosti volbě vládou preferovaných kandidátů bránil. Související otázka nového diecézního rozhraničení se od počátku protahovala kvůli stížnostem mad'arské vlády, respektive mad'arské církve vůči Československu a protikladným majetkovým nárokům československé strany. Československá vláda totiž po válce zabrala na slovenském území všechny velkostatky ostřihomského arcibiskupství a kapituly, dále majetky ostřihomských benediktinů a cisterciáků a konečně pozemky náboženských a vzdělávacích nadací. ${ }^{11}$ Jednání o finální podobu československých diecézí se pro nejednoznačný postoj Vatikánu pobouřeného Marmaggiho aférou v létě 1925 fakticky zastavila. ${ }^{12}$ Obnovena byla teprve na počátku roku 1927 a na počátku roku 1928 byla završena parafováním modu vivendi. ${ }^{13}$

Po vzniku ČSR pobývaly na celém území Slovenska asi 2 miliony katolíků, z nichž polovina žila v oblastech dřívější ostř̌ihomské a satumarské diecéze. Po roce 1918 tak jedna třetina nově ustanoveného slovenského území spadala pod církevní správu ostřihomské arcidiecéze, jejíž ordinář a primas sídlil v Mad’ar-

8 HRABOVEC, Emília. Slovensko a Svätá stolica 1918 - 1939 v kontexte medzinárodných vzt’ahov. In DOBROTKOVÁ, Marta - KOHÚTOVÁ, Mária (ed.). Slovensko a Svätá stolica. Trnava: Slovenský historický ústav v Ríme; Trnavská univerzita, 2008, s. 184-220, zde s. 186. ISBN 9788080822385.

9 Kromě výše uvedené studie (ref. 8), např́klad PEHR - ŠEBEK, ref. 1 s. 92-102 či ŠMíD, Marek. Apoštolský nuncius v Praze. Významný faktor v československo-vatikánských vztazích v letech 1920-1950. Praha: Centrum pro studium demokracie a kultury, 2015, s. 182-193. ISBN 9788073253622.

10 HRABOVEC, ref. 8, s. 196.

11 Stalo se tak na základě zákona o mimořádných přechodných ustanoveních na Slovensku (č. 64/1918 Sb.). Viz níže.

12 V letech 1921-1925 působila v Praze československo-mad'arská subkomise pro církevní záležitosti, kde zasedali zástupci obou stran a měli řešit nevyjasněné otázky ve vzájemných církevních vztazích. K žádné jednoznačné dohodě však nakonec nedošlo. PEHR - ŠEBEK. ref. 1, s. 104.

13 ŠMíD, ref. 9, s. 180. 
sku. ${ }^{14}$ Zbytek slovenských katolíků patřil do oblasti pěti diecézí. Po měsících složitých vyjednávání byl Michal Bubnič jmenován apoštolským administrátorem pro rožňavskou diecézi (1925-1945) ${ }^{15}$ a Jozef Čárský (1925-1962) administrátorem pro košickou diecézi. V květnu 1922 byl ustanoven apoštolský administrátor se sídlem v Trnavě, jenž měl do doby vytvoření nové diecéze, spravovat a duchovně zaopatřovat oblast dřívějšího ostřihomského arcibiskupství na Slovensku. Stal se jím Pavol Jantausch (1922-1947). Karol Kmet'ko (1921-1948) obsadil místo nitranského biskupa, Marián Blaha (1921-1943) banskobystrického biskupa a Ján Vojtaššák (1921-1965) ${ }^{16}$ spišského biskupa. Tři posledně uvedení byli prvními slovenskými římskokatolickými biskupy vysvěcenými po vzniku republiky. Slavnostní akt proběhl v Nitře 13. února $1921 .{ }^{17}$ Společné svěcení se stalo významnou událostí celostátního charakteru. Př́tomni byli nejen představitelé církve, ale též celá řada československých politiků. Nitra tehdy prožila velkolepou oslavu křest'anské minulosti Slovenska a staroslověnské tradice, jež byla pojata jako tradice slovenská a odkazovala k svébytnosti nitranského biskupství a knížectví. Průběh ceremonie svěcení jako by do budoucna předznamenal linii národně sebevědomého chování některých slovenských biskupů v meziválečném období. Jejich veřejné vystupování a jednání v mnoha ohledech skutečně nesplňovaly požadavek loajality, kterou si často nekriticky a maximalisticky nárokovali čeští vedoucí političtí činitelé.

Přes odlišnost $\mathrm{v}$ individuálních povahách lze $\mathrm{v}$ profilech a počinech výše jmenovaných slovenských apoštolských administrátorů zpozorovat četné podobné prvky. Charakterizoval je spíše prostý společenský původ. Skrze nabité teologické vzdělání byli všichni více či méně spjati s Uherskem. Ještě před koncem války se ovšem angažovali v národnostně osvobozujícím společenském životě.

14 V letech 1914-1927 byl ostřihomským arcibiskupem kardinál János Csernoch (Ján Černoch), rodem Slovák ze Skalice. Byl důsledným přívržencem Uherska. Po převratu v Mad’arsku aktivně vystupoval proti Mad’arské republice rad. Později, po nástupu admirála Miklóse Horthyho k moci, stál Csernoch v čele jeho odpůrců - legitimistů, snažících se o návrat Karla I. na uherský trůn.

15 Sídelním rožňavským biskupem se stal až v roce 1939 po přičlenění Rožňavy a dalších oblastí jižního Slovenska k Mad’arsku. V prosinci 1925 byl nicméně jmenován titulárním biskupem scillitanenským.

16 Od roku 1945 byl však Msgr. Vojtaššák pod policejní kontrolou a tudíž téměř neschopen faktického vedení své diecéze. V roce 1951 byl odsouzený za místopředsednictví a aktivity ve Státní radě Slovenské republiky a zejména za výpady proti novému politickému režimu. S krátkými přestávkami si odpykával dlouholetou internaci v slovenských i českých věznicích a nakonec v domově důchodců v Senohrabech.

17 Více o průběhu a významu svěcení LETZ, Robert. Marián Blaha, Karol Kmet’ko a Ján Vojtaššák, profily osobností troch slovenských katolických biskupov. In Historický zborník, 2011, roč. 21, č. 1, s. 58-77. ISSN 1335-8723. 
V roce 1918 se s konečnou platností rozhodli odpoutat od starého Uherska. Karol Kmet'ko a Ján Vojtaššák se v Martině 30. ř́ijna připojili k signatářům Deklarace slovenského národa. Od počátku se též angažovali v Kněžské radě, konsolidačním orgánu duchovenstva v rámci katolické církve na Slovensku. Ještě jako řádoví kněží či kaplani navázali tito mužové spolupráci se SLS, kterou považovali za stranu účinně bránící církev, křest'anské hodnoty a samostatnost slovenského národa. Od konce 20. let vstupovali tito hodnostáŕi s podporou Andreje Hlinky a jeho spolupracovníků stále častěji do otevřené opozice vůči pražské vládě. Jediný Marián Blaha se od Hlinky a jeho strany spíše distancoval. Jejich vzrůstající nesouhlasný postoj s vládní politikou odrážel tradiční sebepojetí kněžské, respektive biskupské autority a dále především postupně nabývanou zkušenost konfrontace jejich tradičních pravomocí, která vedla $\mathrm{k}$ nedůvěře a nezř́íka přerůstala $\mathrm{v}$ nedořešené konflikty. Ilustrativním př́kladem incidentu, který vedl $\mathrm{k}$ hluboké a trvalé skepsi jednoho z církevních hodnostářů k českým vládním kruhům, se stalo zamítnutí vydání cestovního pasu pro Msgr. Vojtaššáka ministrem vnitra Janem Malypetrem. Vojtaššákův záměr odjet v létě roku 1922 do USA, aby se mezi slovenskými krajany pokusil omezit vliv nedávno utvořené Československé církve, byl ministerstvem vyhodnocen jako pokus šíření autonomistického hnutí v prostředí amerických Slováků. Vláda tak fakticky spišskému biskupovi zabránila odcestovat. ${ }^{18} \mathrm{~V}$ roce 1924 na Vojtaššáka navíc v politickém pamfletu ostře zaútočil protikatolicky a protiautonomisticky působící srbský kapitán v tajných službách Teodor Dimitrijevič. ${ }^{19}$ I když spišský biskup svou pastorační cestu do USA, společně s J. Čárskym, M. Blahou a Pavlem Jantauschem, v létě 1926 nakonec uskutečnil u př́iležitosti Světového eucharistického kongresu v Chicagu, nemohl zapomenout na př́koř́i a urážky, jichž se mu ze strany českých vládních kruhů a útočné kampaně v českém tisku tak záhy po jeho jmenování dostalo. Vrat'me se nyní k úsilí čs. vlády o dořešení delimitační otázky slovenských biskupství. Diecéze Nitra, Banská Bystrica byly národně relativně jednolité. Území trnavské apoštolské administratury, Košice, ${ }^{20}$

18 HROMJÁK, Luboslav. S výrazom lásky trvám. Životopis spišského biskupa Jána Vojtaššáka. Spišské Podhradie: Nadácia Kňazského seminára biskupa Jána Vojtaššáka, 2015, s. 136-141. ISBN 9788089170500.

19 DIMITRIJEVIČ, Teodor. Bič boží. Brno 1924. Text pamfletu Vojtaššáka nepravdivě vylíčil jako pyšného a primitivního člověka žijícího v přepychu a hojnosti. Označil jej za odpůrce republiky a za zastánce znovunastolení monarchie na Slovensku v čele s dynastií Cobourg. Tamtéž.

20 Žily zde po převratu jen dvě třetiny Slováků, zbytek tvořili Mad’aři a Rusíni. Katolíci přitom reprezentovali jen 47 \%, uniaté 35 \%. Dále zde žili četní židé a kalvinisté. MATOUŠEK, Karel. V̌̌eobecný zeměpis Slovenska, Země a lidé, sv. 36. Praha: Unie, 1922, s. 143. 
Spiš ${ }^{21}$ a Rožňava ${ }^{22}$ zůstaly národnostně velmi smíšené. Zatímco diecézní hranice v Čechách a na Moravě nepotřebovaly kromě dohody s vratislavskou arcidiecézí větších úprav, nové rozhraničení a s ním související dotace církevně-správních jednotek se významně dotkly též území Podkarpatské Rusi. Také řeckokatolické eparchie prešovská a užhorodská byly národnostně velmi nejednotné, s převahou rusínského obyvatelstva, avšak s početnými mad'arskými a rumunskými menšinami a představovaly zároveň nejchudší z československých biskupství.

Československý stát a římskokatolická církev byly v souvislosti s definováním nových diecézních hranic zaměstnány otázkou neuspokojivě provedené výměny nemovitostí mezi mad'arskou a československou stranou. Mad'arsko systematicky odmítalo československé návrhy na majetková vyrovnání a lpělo na integritě ostřihomské arcidiecéze. Odříkalo slovenským duchovním výnosy z pozbytých statků slovenských církevních subjektů, které se ocitly za mad'arskými hranicemi. Mad’arsko, stejně jako Československo uvalilo po válce na církevní statky vnucenou správu. Mad’arská vláda podporovaná domácí katolickou církví považovala přitom ostřihomskou arcidiecézi za fundament obnovy uherské integrity, která utrpěla prohrou Rakouska-Uherska ve válce a Trianonskou mírovou dohodou. Na tom se shodovaly prakticky všechny poválečné mad'arské vlády bez ohledu na jejich politickou orientaci. ${ }^{23}$ Mad'arští vysocí církevní hodnostáŕi proto na mezinárodním diplomatickém fóru a především v kurii šírili představu o nebezpečí laického a antiklerikálního vlivu české vlády na slovenské katolíky. Česká strana se proti těmto výpadům a irendentistickým pokusům ${ }^{24}$ bránila snahou o uzavření dohody mezi ČSR a Svatým stolcem, jež by ukončila stav přerušených diplomatických styků po Marmaggiho aféře a zároveň řešila problém jurisdikce cizích ordinářů na československém území. Za účelem vyjednání dohody s Vatikánem byl v roce 1927 pozván do Prahy podsekretár Kongregace pro mimořádné církevní záležitosti Pietro Ciriaci, jenž byl v únoru 1928 jmenován pražským nunciem. V pořadí třetí zástupce Svatého stolce v ČSR vystupoval od počátku nástupu do své funkce jako zkušený vyjednavač

21 Dle statistických dat z roku 1922 žilo v župě jen 58 \% Slováků, dále 7 \% Mad’arů, $23 \%$ Němců a $8 \%$ Rusínů. To se pak odráželo i v náboženském složení obyvatelstva (68 \% katolíků, $11 \%$ uniatů, 15 \% luteránů a 4 \% židů). MATOUŠEK, ref. 20, s. 195.

22 Sever Gemeru (Gemersko-malohontské župy) byl z 90 \% slovenský, východ (Rožňavský okres) jen z 50 \% slovenský a jižní cíp (okres tornalijský) z 90 \% mad’arský. Slovenské okresy byly převážně evangelické, tornalijský kalvínský. MATOUŠEK, ref. 20, s. 199.

23 HRABOVEC, ref. 8, s. 204.

24 SOUKUPOVÁ, Martina. Rothermerova akce z roku 1927. Pokus o revizi trianonského míru. In Dvacáté století, 1/2009, s. 101-113. ISSN 1803-750X [1]. Mad’arsko ve svém úsilí systematicky využívalo $\mathrm{k}$ volání po revizi hranic a restituci sporného majetku též mad’arskou menšinu na jižním Slovensku. 
a především konciliantní prostředník, který chce napomoci konsolidaci vzájemných československo-vatikánských vztahů.

\section{Vzdor či „povinnost sebeobrany"?}

„Akási kliatba leži na katolikoch slovenských alebo Boh ich preháña cez oheñ očistcový. Len keby sme pri tom neutratili večné a všeobecné dobrá. “

$(\text { Jan Vojtaššák })^{25}$

Postoj Svatého stolce vůči Československu se po urovnání diplomatické roztržky, vyvolané v červenci 1925 oslavou svátku mistra Jana Husa, jevil vstřícný a konciliantní. Podobnou vstřícnost očekávali vládní představitelé, především ministerstvo zahraničí též ze strany domácího kléru. Nově jmenovaní slovenští biskupové se logicky snažili bránit církev a věřící v podmínkách nového státu. Intenzivně se oddávali především pastorační, charitativní a nadační činnosti. Zároveň odhodlaně obhajovali svá práva v oblasti školství a charity a bránili se tlaku socialistických stran a pokrokových hnutí, které v parlamentu prosazovaly tvrdší politiku proti církvi. Ve svém jednání vyzdvihovali především svou trvalou péči o blaho věřících. Výhodu vzájemného respektu a spolupráce církve a státu zdůraznili ostatně slovenští hodnostáři v memorandu adresovaném prezidentu T. G. Masarykovi 26. února 1919: „Občanská a duchovní moc si mají vycházet vstřic, protože církev i stát maji moc nad týmiž poddanými [...] Církev proto neruši svazkĩ ji se státem spojujícich, leda by toho vyžadovala povinnost sebeobrany, kdežto státnická zkušenost posledních století opět a opět ukázala, že stát jen ziskává, šetří-li těchto vztahư. " ${ }^{26}$ Slovenští biskupové hlavě státu jasně popsali jejich představu nevyhnutelnosti sebeobrany vůči př́ípadným bezprávím ze strany vlády. Naopak od ní očekávali, že je bude podporovat, a to včetně otázky majetkového zaopatření.

Hospodaření na církevních statcích, jež se v důsledku poválečného materiálního i morálního rozvratu ocitly zejména na východě republiky ve zbídačeném stavu, představovalo pro církev skutečně nesnadnou úlohu. Tamní biskupové se potýkali s úbytkem zemědělského výnosu, s narůstajícími dluhy, zejména v roce 1919 s nekontrolovaným rozkrádáním majetku, k němuž docházelo v souvislosti

25 ANM, f. E. Jelen, k. 1. Dopis J. Vojtaššáka A. Hlinkovi, 8. 2. 1929. V dopise Vojtaššák předestírá, že by mohl hlavní slovenský předák agrární strany, ministr M. Hodža ztratit své postavení a funkci, kdyby se veřejně mluvilo o jeho souhlasu k odevzdání 23 milionů korun Mad'arsku, respektive kardinálu Černochovi jakožto kompenzaci za pozbylé ostřihomské církevní statky.

26 KONÍČEK, Jiří. Modus vivendi v historii vztahů Svatého stolce a Československa: církevné-politický vývoj v letech 1918-1993. 2. vydání. Olomouc: Společnost pro dialog církve a státu, 2005, s. 36. ISBN 8023960733. 
s vpádem bolševických oddílů Béla Kuna na slovenské území. ${ }^{27}$ Po roce 1919 se především část církevních beneficiátů zdržovala mimo slovenské území. Uvolněná biskupství i jiná místa, dříve obsazená mad’arskými duchovními, tak byla ponechána svému osudu. Vláda proto $\mathrm{v}$ srpnu 1919 pověřila ministra s plnou mocí pro správu Slovenska, aby na základě zákona o mimořádných přechodných ustanoveních na Slovensku (č. 64/1918 Sb.) uvalil na nemovité i movité katolické církevní majetky na Slovensku dočasnou vnucenou státní správu. Vnucená správa měla být nicméně pouze dočasná a byla svěřena smíšené komisi za předsednictví slovenského episkopátu.

V ČSR nebyla po převratu provedena plánovaná rozluka. Nadále tak přetrvával rakouský model státní církve, což znamenalo, že stát církev finančně zabezpečoval, za což si nárokoval zásahy do jejího vnitřního fungování. To se projevovalo nejen $\mathrm{v}$ jeho nároku na ius nominandi biskupů, ale též v zásazích do hospodářských záležitostí, konkrétně v jednáních o delimitaci a dotaci diecézí. Vize státu a slovenského episkopátu se v tomto ohledu ovšem výrazně rozcházely. Československé vládní kruhy se cítily částečně uspokojeny podpisem Trianonské smlouvy. Nechtěly př́liš dráždit revanše chtivé Mad'arsko, připouštěly tudíž jisté nezbytné ústupky. V pokusech o optimalizaci přijatelných požadavků, předložených ze strany Mad’arska a Svatého stolce, ovšem vedení státu naráželo na nepochopení slovenských biskupů, kteří navzdory svým bývalým církevním vazbám v rámci Uherska vnímali Mad’arsko jako nelegálního uchvatitele slovenských církevních majetků. Československo nadto pro mnohé slovenské hodnostáře stále zřetelněji představovalo proticírkevně zaměřený stát, který se nedostatečně staví na obhajobu jejich práv.

Katolická církev potřebovala finanční prostředky na charitativní činnost, nemocniční péči, školská zařízení a k údržbě církevních staveb. Uchování společenského vlivu bylo pro mnohé její čelní představitele podmíněno udržením si jisté právní suverenity a majetkové nezávislosti. Již v první polovině 20 . let se navíc v prostředí slovenské církevní hierarchie objevila myšlenka existence samostatné slovenské církevní provincie, která po podpisu modu vivendi dále sílila. Sídlo nové arcidiecéze mělo být bud' v Nitře, nebo v Bratislavě. Vláda však zprvu neměla na vytvoření samostatné slovenské církevní provincie skutečný zájem. Úspěšným popřevratovým odstraněním mad'arských hodnostářù z biskupských stolců totiž již bezprostředně nehrozilo zasahování cizích ordinářù do vnitřních církevních záležitostí na Slovensku. Členové vlády a předně ministr Edvard Beneš však tento svůj postoj kvůli kontinuálnímu tlaku sloven-

27 Tristnímu a do jisté míry anarchickému stavu slovenských biskupství během války a po ní napomáhala také skutečnost, že mnozí mad'arští ordináři dosáhli na sklonku války již vysokého věku a netěšili se dobrému zdraví. 
ského episkopátu, jenž nalezl zastání ve Vatikánu, ${ }^{28}$ po červnu 1931 přehodnotili. I v tomto ohledu projevili biskupové na Slovensku výraznou snahu vymanit se z dozoru čsl. státních úřadů a zároveň zdůraznit zaslouženou váženost, jíž se v ř́mské kurii těšili za svou oddanou službu.

Konečně hospodářské krize a nárůst politického autonomismu na Slovensku ve třicátých letech postupně přivedly slovenské biskupy do pozice více či méně ofensivní sebeobrany, kterou členové vládních komisí vnímali jako protistátní činnost. Také Svatému stolci ze zřejmých důvodů záleželo na tom, aby byla zachována jakási alespoň částečná životaschopná rovnováha mezi majetkovým vlastnictvím jednotlivých diecézí. Nepřál si ani př́iliš bohatých biskupství, zároveň se strachoval o chátrající a zadlužené církevní statky. Vatikán proto doufal, že se na oplátku za svou vstřícnost při jednáních o delimitačních otázkách na Slovensku a zbylém území setká s vstrrícností v otázce jejich majetkového zaopatření.

\section{První spory o disponování církevním majetkem}

Svatý stolec pověřil na základě prvního článku modu vivendi $i^{29}$ jednáním o ustanovení nových diecézních hranic dvě na sobě nezávislé komise. První komise byla jmenována $\mathrm{z}$ delegátů všech zainteresovaných diecézí za předsednictví pražského nuncia. Druhá, tzv. vládní komise, byla sestavena československou vládou ze zástupců diecézí a oborových expertů. Při zasedání druhé schůze vládní komise na konci června 1928 projevil její předseda, vyslanec Kamil Krofta, jistý optimismus, když konstatoval, ,že většina členů slovenského episkopátu je již získána pro základni myšlenky našeho [tj. státního] návrhu na nové rozhraničeni slovenských diecési “ ". ${ }^{30} \mathrm{Na}$ stejné schůzi upozornil ovšem př́tomné další člen komise František Machát, ${ }^{31}$ „„̌e územni rozloženi cirkevních statků na Slo-

28 Archivio Segreto Vaticano (dále ASV), f. Nunziatura Cecoslovacchia IV, busta 61, fasc. 527, pos. 16a, fol. 269-274 či AMZV, f. Zastupitelský úřad Vatikán (dále ZÚ), k. 7. Nota státního sekretariátu Sv. stolce čsl. ministerstvu zahraničí z 11. 6. 1931 se stanovisky o delimitaci a dotaci čsl. diecézí. Samostatná slovenská církevní provincie vznikla nicméně až v roce 1977. Více k této otázce v meziválečném období LETZ Róbert. Úsilia o vytvorenie slovenskej cirkevnej provincie v rokoch 1918 - 1938. In MULÍK Peter (ed.). Katolícka cirkev a Slováci. Úsilie Slovákov o samostatnú cirkevnú provinciu. Bratislava: Bernolákova spoločnost', 1998, s. 43-61. ISBN 8096787411.

29 Text otištěn např. ŠMíD, Marek et al. Československo a Svatý stolec. III. Diplomatická korespondence a dalši dokumenty 1917-1918. Praha: Masarykův ústava a archiv AV ČR, 2015, dok. č. 134, s. 564-565. ISBN 9788086495743.

30 AMZV, f. ZÚ, k. 6, Zápis o II. schůzi vládní komise pro delimitaci a dotaci diecézí, 26. 6. 1928.

31 František Machát byl středoškolský profesor zeměpisu a dějepisu. Působil též jako lektor didaktiky zeměpisu na Př́rodovědecké fakultě UK. Publikoval vlastivědné učebnice a působil jako člen vládních expertních komisí. 
vensku jest neudržitelné. Hlavni zájem slovenských biskupů jest, aby méli statky ve svých diecésich a rozloženy tak, aby jejich správa byla co nejlevnější a nejsnazši “ ".32 Za tímto účelem navrhl Machát jako řešení rozsáhlé vnitřní výměny církevních nemovitostí a dále systém vzájemných peněžních kompenzací, které by byly dotovány výtěžkem $\mathrm{z}$ prodeje části církevních statků v rámci pozemkové reformy. ${ }^{33}$

Dluhy církevních statků na Slovensku přitom narůstaly. Část slovenského episkopátu proto $\mathrm{s}$ tímto vládním plánem nesouhlasila a začala hledat zastání právě u Svatého stolce a jeho pražského zástupce. V polovině ledna 1929 požádal sbor slovenských biskupů P. Ciriaciho, aby podpořil zř́izení biskupy vedené církevní komise pro správu církevního majetku na Slovensku. Stát si totiž činil nárok na výkon vrchního patronátu nad veškerým církevním majetkem. Ve snaze snížit dluh slovenských církevních subjektů totiž ministerstvo školství a národní kultury v podstatě bez souhlasu hodnostár̆ů schvalovalo prodej slovenských biskupských a kapitulních statků. Biskupové se chtěli zbavit mad'arské kurately, nehodlali však ani akceptovat kuratelu vlastního státu. Episkopální sbor proto pověřil Jána Vojtaššáka ustanovením nové církevní komise a jmenoval jej jejím předsedou s plnou mocí ${ }^{34}$ Spišský biskup se svého úkolu zhostil ihned s velkým odhodláním a energií. Neúnavně vládní straně adresoval stanoviska a námitky biskupů s cílem hájit jejich majetkové zájmy. V listu z 21. ledna 1929 Vojtaššák slovenské hodnostáře informoval, že se mu zatím nedaří zvrátit rozhodnutí o sekvestru slovenského církevního majetku svěřeného do správy Likvidační komise ustanovené v roce 1923, jež nahrazovala Centrální komisi pro správu církevních statků. ${ }^{35}$ Slíbil ovšem, že své snahy a tlak na ministerstvo zahraničí zintenzivní. ${ }^{36} \mathrm{~V}$ polovině února požádal nuncia, aby na ministerstvu urgoval

32 „Je zájmem státu, aby chudoba jednotlivých diecésí zvl. diecésí řecko-katolických přestala, nebot' pak stát nebude se museti o tyto biskupy majetkově starati. Prováděni modu vivendi dává ke všem těmto věcem velmi dobrou přiležitost, které je nutno využiti. “ Tamtéž.

33 Kamil Krofta se přitom domníval, že ,,[Svatý stolec] nemaje zájmu na tom, aby mezi biskupy byla přilišná disparita majetková, ani aby biskupové byli přilišnými boháči, bude nakloněn nyni provésti př́padně dosti značné presuny neb kompensace při rozdělováni církevního majetku slovenského. "Tamtéž.

34 ASV, f. Arch. Nunz. Cecoslovacchia, an. 1928 (1929), busta. 61, fasc. 576, pos. 42, fol. 19r.

35 Dne 14. listopadu 1929 byla v Bratislavě konečně též vládou potvrzena a zř́zena nová církevní správní komise pod předsednictvím Msgr. Vojtaššáka. Dohližela pouze na správu sporných majetků, jež se po roce 1918 ocitly na bývalém území ostřihomské diecéze. Existence této církevně správní komise nijak nerušila vnucenou správu všech církevních statků odevzdaných do rukou P. Jantausche. KONÍČEK, ref. 26, s. 117.

36 Archiv spišské diecéze, f. Protokoly odeslané a došlé korespondence (dále Diecézní protokoly), Oběžník spišského biskupa J. Vojtaššáka, 21. 1. 1929: „Úctive hlásim, že 17. t. m. nepodarilo sa niže písanému, hociako s každej strany pripravenému a obrnenému prerazit' frontu $v$ Likvidačnej Komisii, ktorá, jako si sama pochval'uje ,stoji na betone '. Útok sa musí započat' 
schválení církevní komise biskupů. Ministerstvo zahraničí se mělo pro jakékoli prŕpadné dotazy obrátit na poslance Andreje Hlinku a Josefa Tisa. ${ }^{37}$

Slovenský episkopát přirozeně podporoval katolický politický proud. Většina biskupů se angažovala v SL’S už za Rakouska-Uherska. Ve spolupráci s l'udáky vedli boj nejen proti bezvěrectví, liberálním a pokrokářským proudům, ale zapojili se též do národní agitace. Spojující postavou v jejich politické činnosti byl A. Hlinka. Zatímco v druhé polovině dvacátých let spolupracovali biskupové a dřívější podporovatelé SL'S K. Kmet'ko a P. Jantausch hlavně s lidovci, M. Bubnič a J. Čársky spolupracovali nadále spíše s HSLSS. ${ }^{38}$ Míra osobní angažovanosti slovenských biskupů vůči politice Hlinkovy strany se lišila. Trvalé neshody mezi centrální pražskou vládou a slovenským episkopátem ovšem jistým způsobem vháněly tyto vysoké církevní hodnostáře do náruče slovenského autonomistického hnutí. Po úspěších HSLS v parlamentních volbách v roce 1925 slovenští duchovní zřetelně konstatovali ohromný nárůst popularity l'udáckého politického programu mezi slovenskými katolickými voliči a byli tímto výsledkem $\mathrm{v}$ podstatě uspokojeni.

V situaci hospodářské krize, která se odrazila také na poklesu zemědělských výnosů, se slovenští duchovní stávali ještě radikálnějšími ve svých požadavcích. Českoslovenští státní představitelé si byli této situace plně vědomi. Neměli zájem na tom, aby podkopávali hospodářskou základnu nejsilnější církve. Vláda, angažovaná $\mathrm{v}$ otázce sporného církevního majetku v zahraničí, se proto snažila slovenskému episkopátu vyjít vstř́ic a tento problém v součinnosti s příslušnými ministerstvy a výše uvedenými komisemi co nejefektivněji vyřešit. Československá republika přitom Mad'arsku ještě před uzavřením modu vivendi zaplatilo 23 milionů korun, konkrétně 7 milionů ostřihomskému biskupství a 16 milionů ostřihomské kapitule. Stát si na tuto velkou částku půjčil s vysokým 10\% úrokem a byl tímto diplomatickým krokem vůči Mad'arsku dlouhodobě nezanedbatelně zatížen. ${ }^{39}$ Vládní delimitační komise navrhla slovenskému episkopátu pozbyté ušlé důchody z vlastnictví dřivější části ostřihomské arcidiecéze do budoucna nahradit formou peněžitých kompenzací jednotlivým biskupstvím. S tímto řešením se však část slovenského episkopátu nehodlala spokojit.

Objevily se zejména obavy o výnosy církevních lesních statků. Pozornost vládní dotační komise získal dále spor o vinice $\mathrm{v}$ majetku spišské diecéze ležící na mad’arském území. Msgr. Vojtaššák komisi opakovaně tvrdil, že vinice jsou pro spišské biskupství a kapitulu ,životní podmínkou“, nebot' oba subjekty potřebují ,,nemovitosti a přirodniny“, které jsou jediné schopné zajistit jí trvalý

znova. [...]. “

37 ASV, Arch. Nunz. Cecoslovacchia IV, an. 1928 (1929), busta. 61, fasc. 576, pos. 42, f. 21 r.

38 LETZ, ref. 17, s. 74.

39 ANM, f. E. Jelen, k. 1, český opis Dopisu K. Krofty kardinálu E. Pacellimu, 2. 11. 1934. 
a jistý důchod, nikoli peníze nabízené státem. ${ }^{40}$ Prohlašoval, že souhrnný majetek spišské diecéze $\mathrm{v}$ Mad’arsku tvořený především zmíněnými vinicemi vynášel ročně asi 250000 Kč. Spišský biskup proto ministerstvo zahraničí (respektive skrze něj státní pozemkový úradad a ministerstvo financí) žádal, aby ze svého kompenzačního návrhu, jenž měl přerozdělit státem stanovené finanční náhrady, kalkulaci spišských nemovitostí ležících v Mad’arsku zcela vypustilo, se zdůvodněním, že se jedná o soukromý církevní majetek. Ministerstvo vnitra nechalo ovšem Vojtaššákova tvrzení prověřit experty. Závěr Jaroslava Hendrycha, oborového rady v delimitační komisi za ministerstvo školství, zněl, že vinice spišské diecéze ležící v Mad'arsku nejsou tak výnosné, nebot' vzhledem k dovoznímu clu do Československa nenacházelo toto víno odbyt.

Hlavní zdroj př́ijmů spišské diecéze a kapituly představovaly ve skutečnosti lesy. ${ }^{41}$ Biskup Vojtaššák pronajímal podle experta státní komise Macháta slovenské dřevařské firmě právo kácení v mensálních lesích, za což dostával ročně asi 2 miliony korun. ${ }^{42}$ Toto zjištění do značné míry relativizovalo Vojtaššákovu deklarovanou životní nezbytnost spišských vinic za hranicemi. Výrazný zdroj př́ijmů pro biskupství skutečně představovala pila v obci Hranovnica. Pozdější obvinění, že byl J. Vojtaššák po nějaké období sám majitelem či spolumajitelem této pily, z níž mu měl ročně údajně plynout zisk 3 milionů korun, zůstávají nicméně na úrovni spekulací ${ }^{43}$ Každopádně ještě dř́ve než na východě Slovenska propukla kulminační fáze hospodářské krize, projevoval se spišský biskup jako starostlivý a pečlivý hospodár. S jemu svěřeným majetkem se snažil zacházet zodpovědně, což odpovídalo jeho skromnému původu. Chtěl efektivně hospodařit a investovat podle vlastního úsudku pro dobro věřících. Domníval se, že on sám nejlépe ví, co je pro ně potřebné a co si zaslouží. Velice nelibě proto nesl trvající nucenou správu církevního majetku.

\section{Rozepře o existenci rožňavské diecéze}

Kromě obavy o hospodářské zajištění svých diecézí, k níž se níže vrátíme, trápila slovenské biskupy stejně jako stát, v souvislosti s prováděním vnitřní delimitace diecézních hranic, především jejich národnostní složení. V této souvislosti

40 Archiv spišské diecéze, fond Protokolů odeslané a došlé korespondence, spis č. 661. Dopis Vojtaššáka na ministerstvo zahraničí, 10. 3. 1931.

41 HROMJÁK, ref. 18, s. 151.

42 AMZV, f. ZÚ, k. 7, Zápis z XX. Schůze zasedání delimitační komise, 6. 5. 1931. „Dodatečné námitky slovenských biskupů $k$ dotačnímu plánu jsou pro vládu nepochopitelné a jistým zklamáním. "

43 Účelem komunistické propagandy bylo Vojtaššáka vykreslit jako třídního nepřítele dělníků a rolníků, kořistnického velkostatkáře. Církevní historik a autor Vojtaššákovy nedávné biografie výše uvedená obvinění popírá. HROMJÁK, ref. 18, s. 152. 
vznesla státní delimitační komise již na začátku svých jednání návrh na zrušení rožňavské diecéze a přeskupení jejích far do sousedních biskupství.

$\mathrm{Z}$ celkového počtu původních 101 rožňavských far se po rozpadu monarchie nacházelo 19 far s 60000 věřícími na cizím území. Jednalo se přitom o nejbohatší farnosti. Na území ležícím na Slovensku žilo 60000 slovensky mluvících katolíků, dále 80000 mad'arských katolíků a 9000 Němců. ${ }^{44}$ Kromě nesnadného národnostního faktoru zde panovala pro katolickou církev též problematická konfesijní situace. $Z$ celkového počtu téměř 150000 obyvatel rožňavské diecéze ležící na slovenském území byla více jak polovina augsburského vyznání. Mezi zde žijícími Mad'ary bylo dále velké množství kalvinistů. František Machát ve svém rozboru pro delimitační komisi zdůraznil, že zdejší slovenští katolíci jsou převážně chudí rolníci, existenčně mnohdy závislí na spoluobčanech jiné národnosti a zároveň nijak zvlášt’ „národnostně uvědoměli'“. Machát dále negativně hodnotil, že se v rožňavském biskupství udržuje poměrně nákladný biskupský administrativní aparát a pedagogický sbor (v biskupském semináři na pouhých 8 studentů připadali 4 profesoři atd.), což vhledem $\mathrm{k}$ hospodaření biskupství způsobuje deficit, který musí hradit stát.

Ministr Beneš, jeho zástupce K. Krofta, ale též lidovecký lídr Jan Šrámek či vládní referent pro slovenské církevní záležitosti, probošt Karol Anton Medvedský byli přesvědčeni, že duchovní rožňavské diecéze setrvávají pod silným vlivem mad’arského kléru. Samotného biskupa M. Bubniče považovali za politicky nespolehlivého a věrného služebníka bývalého ostřihomského arcibiskupa Jána Csernocha. ${ }^{45}$ Vzhledem k těmto okolnostem státní komise navrhovala, aby bylo rožňavské biskupství územně rozděleno mezi sousední diecéze a náhradou za ni měla být nově utvořena bratislavská, respektive trnavská diecéze. Rožňavský biskup podpořen dalšími ordináři se ovšem provedení tohoto návrhu téměř okamžitě vzepřel. Spor o Rožňavu se tak stal jednou z překážek a důvodem průtahů $\mathrm{v}$ československo-vatikánských vyjednáváních o definitivním uspořádání diecézí. Přetrval až do uzavření dohody s kurií o provedení modu vivendi v květnu 1935, jež stanovila zachování rožňavské diecéze.

Biskup Bubnič pravidelně vyzdvihoval, že zachování Rožňavy s jejími slovenskými katolíky bude účinnou hradbou proti mad’arskému a zároveň kalvínskému ohrožení. V dopise řeckokatolickému biskupu prešovské eparchie Pavlovi Petrovi Gojdičovi na konci roku 1928 Bubnič Rožňavu označil př́mo za ,,lapis offensionis štátu proti neprajným živlom “. Požádal Gojdiče coby svého křest’anského , pobratima“, aby ministerstvu zahraničí doporučil biskupství zachovat. ${ }^{46}$

44 AMZV, f. ZÚ, k. 6, Návrh na ohraničení nových diecézí, 12. 6. 1928.

45 ŠMíD, ref. 9, s. 186.

46 ASV, Arch. Nunz. Cecoslovacchia IV, busta 61, fasc. 527, pos. 16a, fol. 19rv-21. Dopis M. Bubniče P. P. Gojdičovi, 27. 12. 1928. 
Proti dismembraci Rožňavy se v květnu 1931 rázně vyjádřil také košický biskup Jozef Čársky, jenž v roce 1925 krátce zastával funkci rožňavského apoštolského administrátora. V námitkách předložených delimitační komisi popsal Čársky Rožňavu coby území mající ,,velký význam pro národnostní upevnění živlu slovenského " ${ }^{47} \mathrm{~V}$ zásadě byl košický biskup především proti rozšíření své vlastní diecéze o další farnosti z rožňavské (25 mad’arských far) a ze satumarské diecéze (45 většinou mad'arských far). Čárského obavy umocňovala skutečnost, že jeho vlastní košická diecéze byla sama významně ohrožována působením promad'arsky se profilující košickou kapitulou. Velká část majetku košické diecéze ležela nadále $\mathrm{v}$ Mad’arsku, mnozí košičtí církevní hodnostáři se tudíž bránili „odmad'arštění“ biskupství z obavy, že by byli připraveni o výtěžky církevních statků, které dosud z Mad'arska dostávali. Odmítavé postoje biskupů Bubniče i Čárského kritizovala vládní komise, $\mathrm{k}$ níž se stále častěji přikláněl také $\mathrm{P}$. Ciriaci.

V rozhovoru s československým vyslancem ve Vatikánu Vladimírem Radimským v červnu 1931 se tak pražský nuncius zmínil ,několikráte o našich slovenských biskupech s despektem; nemaji prý charakteru ani širšiho rozhledu, etc. a podléhají svému nejbližšimu okoli, okamžitým vliviom, takže na ně není spolehnutí. Vưči vládě vystupují jinak, jinak jednají s ním, a zase jinak s Vatikánem “. ${ }^{8}$ $\mathrm{O}$ necelý měsíc později sdělil nuncius Ciriaci v důvěrném rozhovoru ministru Benešovi a vyslanci Kroftovi, že Vatikán vzhledem $\mathrm{k}$, ,žejmě lživým tvrzením biskupa Bubniče u Svatého stolce “ již ve věci zrušení Rožňavy nejspíš nebude brát zřetel na osobnost nynějšího rožňavského administrátora. Ciriaci dodal, že on sám se od něho nadobro odvrátil. ${ }^{49}$

Svatý stolec dostatečně chápal situaci složitého národnostního složení, která panovala na jižním Slovensku. Mad’arští církevní hodnostáři se sice v kurii tradičně těšili dobrému postavení, Vatikán však oficiálně zastával neutralitu a respektoval hranice ČSR a jeho snahu vymanit čs. diecéze ze závislosti na zahraničních provinciálech. Římskou kurii kromě národnostního složení nejspíš znepokojovaly zejména nuzné sociální poměry, které v rožňavské diecézi panovaly. Zkušenost ukazovala, že sociálně slabé obyvatelstvo se snadno nechávalo strhnout předáky socialistického či komunistického tábora.

Z dalších pramenů vyplývá, že ještě zásadnější despekt choval Ciriaci k Msgr. Vojtaššákovi. Dle jeho mínění přesahoval spišský biskup svoje pravomoci, choval se povýšeně vůči vyšší církevní hierarchii a svými nepřiměřenými požadav-

47 AMZV, f. ZÚ, k. 7, Zápis z XX. schůze zasedání delimitační komise, 6. 5. 1931.

48 AMZV, f. ZÚ, k. 7, Radimského zpráva na ministerstvo zahraničí týkající se jeho rozhovoru s Ciriacim hodnotící notu státního sekretariátu ve Vatikánu, 16. 6. 1931.

49 AMZV, f. ZÚ, k. 7, Zpráva z rozhovoru Ciriaciho s ministrem Benešem a K. Kroftou o postoji Vatikánu vůči čs. návrhům na úpravu poměrů na Slovensku, 6. 7. 1931. 
ky zdržoval jednání s kurií. Kroftovi nuncius dokonce opakovaně tvrdil, že by Vojtaššák mohl být $\mathrm{z}$ důvodu svéhlavosti nahrazen $\mathrm{v}$ diecézi jiným biskupem. ${ }^{50}$

Problém Rožňavy se ovšem navzdory nunciovým kritickým názorům na některé slovenské biskupy nikam výrazně neposunul. Svatý stolec nepřijal delimitační plán československé vlády, který obsahoval požadavek na zrušení rožňavské diecéze. Spor tedy pokračoval dál. Msgr. Bubnič jej v záŕí 1931 téhož roku ostře komentoval ve svém proslovu předneseném na biskupské konferenci v Olomouci. Před plénem v podstatě obvinil státní kruhy z toho, že raději podporují mad'arské kalvínské obyvatelstvo nežli katolickou slovenskou diecézi. ${ }^{51}$ Ve svém proslovu se zároveň snažil očistit od dřivějších podežrení týkajících se jeho domnělých mad'arónských styků a postojů, proti němu vznešených ze strany J. Šrámka a F. Macháta. ${ }^{52}$

Roztrpčený rožňavský biskup se ovšem spíše nežli pochopení katolických hodnostářủ v Olomouci dočkal podpory slovenských l’udáků v čele s A. Hlinkou. Slovenská strana l'udová stejně jako vládní kruhy viděla v národnostním složení jižního Slovenska nebezpečí. Zachování rožňavské diecéze vnímala ovšem nejen jako prostř̌edek boje proti zdejším mad’arským luteránům a kalvinistům, ale zároveň jako nástroj politického boje vůči neustávajícím protikatolickým útokům státu. L'udácký deník Slovák tak centrální vládě vyčítal, že ve své snaze o zrušení Rožňavy nepř́mo podporuje mad’arské kalvínské obyvatelstvo a tudíž politickou iredentu. Navrch zdůraznil, že slovenská biskupství nejsou jednoduše politicky dělitelná, jelikož podobná rozhodnutí jsou pouze interní záležitostí církve. ${ }^{53}$ Ministerstvo zahraničí však od rozdělení Rožňavy nehodlalo ustoupit. Slovenskému episkopátu nabídlo výměnný obchod - budou-li ordináři ochotni Rožňavu obětovat, ministerstvo zahraničí akomoduje své požadavky ohledně pozemkové reformy na slovenských církevních statcích i z ní plynoucí dotační plán. Biskup Bubnič označil tuto nabídku doslova ,, terorem “.54

50 AMZV, f. ZÚ k. 7, Tamtéž.

51 ZAOpO, fond Arcibiskupství Olomouc, kt. 1317, f. 41-45., ,[Stát] ponecháva na tomto istom území čiročisto mad'arské, kalvinské biskupstvo, za ktorým stoji jedna silná, mad'arská politická strana, takzvaná národnomad'arská [...] Na theologiu mad'arských kalvínov v Lučenci ministerstvo zdravotnictva dalo indirektne $800.000 \mathrm{kč}$. Dalo sa to Ymke, ale vopred sa vedelo a bolo ustálené, že celé poschodie bude slúżit' pre mad'arskú, kalvinskú theologiu. Mad'arskí kalvíni a luteráni ledva čakajú na srušenie katolického biskupstva a na splnenie ích dávnej túžby. “

52 Dr. František Machát byl v letech 1919-1920 vyslán vládními kruhy na Slovensko a Podkarpatskou Rus, aby zde prostudoval a popsal jejich zeměpisnou a národnostní stránku a prozkoumal též církevní poměry. Již tehdy vypracoval návrh na rozhraničení slovenských diecézí, který počítal se zrušením rožňavské diecéze.

53 Slovo k cirkevno-politickej otázke na Slovensku v spojení s „modus vivendi“. In Slovák, 6. 1. 1933, roč. XV., s. 2

54 ANM, f. Eduard Jelen, k. 1, Dopis E. Jelena vyslanci V. Radimskému, z 22. 12. 1931. 
Nesmírná složitost přeskupení rožňavských far v rámci sousedních diecézí, spojená s trvalým odporem slovenské církevní hierarchie, vedla nakonec k zachování územně nejmenšího slovenského biskupství. Na základě apoštolské konstituce z 2. záŕí 1937 (Ad ecclesiastici regiminis incrementum) byla z rozhodnutí Svatého stolce Rožňava zachována a společně s košickou a spišskou diecézí vyňata z podřízení jagerské provincii, $\mathrm{k}$ níž dosud oficiálně náležela.

\section{Gradace sporů o církevní majetek a zákulisní jednání části slovenského episkopátu (1932-1935)}

Obavy o hospodářské zajištění slovenských diecézí jak na straně hodnostářů, tak na straně státu v dalších letech nejen přetrvávaly, ale dále gradovaly. Významné jablko sváru mezi republikou a slovenskou církevní hierarchií představovala pozemková reforma.$^{55}$ Ćást církevního majetku měla být v ČSR dle záborového zákona (č. 215/1919 Sb.) církvi odebrána a přerozdělena drobným vlastníkům. ${ }^{56}$ Navzdory tradičnímu nesouhlasu Svatého stolce s uplatňováním pozemkových reforem na církevní vlastnictví došlo ze strany Vatikánu při finálních jednáních o modu vivendi $\mathrm{k}$ souhlasu s provedením reformy též na čs. církevních statcích. $\mathrm{V}$ praxi to znamenalo, že se tyto statky (zemědělská půda jednoho subjektu nad 150 ha) ocitly v tzv. záboru a byly spravovány v rámci vnucené zprávy. Slovenský episkopát se s touto skutečností těžce smiřoval.

Velké zadlužení slovenských diecézí koncem roku 1931 přimělo slovenské apoštolské administrátory $\mathrm{k}$ naléhavé žádosti k čs. vládě. Slovenské církevní statky vykazovaly v tomto roce pasiva odhadovaná delimitační komisí na 40 milionů korun. Byla důsledkem půjček potřebných na opravy a zabezpečení chodu po válce poničeného církevního majetku a dále dlužné částky, kterou ČSR vyplatilo Mad’arsku za ostřihomský majetek ležící na slovenském území (23 milionů Kč) a úroků vážících se k této státní půjčce. Ve většině případů stát tyto závazky převzal, a proto odmítal církevním subjektům vrátit statky bez zohlednění těchto dluhů. Biskupové ovšem naléhali, aby stát tuto situaci sanoval tím, že by část dluhu bud' přímo zaplatil, nebo alespoň poskytl bezúročnou půjčku. ${ }^{57}$ Minister-

55 V Radimského zprávě pro ministerstvo zahraničí týkající se jeho rozhovoru s Ciriacim se mimo jiné dočteme: , Klič k celému modu vivendi je v jednání s Mons. Vojtaššákem o provedení pozemkové reformy. [...] Kdyby Mons. Vojtaššák nevyhovoval, mohl by být nahrazen někým jiným. Ze slovenských biskupů se Mons. Ciriacimu zamlouvá nejspíše ještě Mons. Kmet’ko. “ AMZV, f., ZÚ k. 7, 16. 6. 1931.

56 Přes počáteční agilní postup $\mathrm{v}$ tomto ohledu plynoucí z porevolučního antiklerikálního nadšení, došlo nakonec díky protestům katolické církve a za pomoci politického katolicismu k záboru přibližně jen $16 \%$ církevní půdy.

57 „Konečně žádali páni biskupové slovenští, aby pozemková reforma dále na církevních statcích slovenských nebyla prováděna, poněvadž za dnešni krise tyto statky samy již nejsou dostatečnou dotací, uváži-li se velká břemena církevnich jednotek. "ANM, f. E. Jelen, k. 1, Dopis E. 
stvo zahraničí tuto žádost zamítlo, bylo si však vědomo potencionálního nebezpečí př́iliš důsledného provádění pozemkové reformy, a proto uložilo Státnímu pozemkovému úřadu, aby byl v jednáních o postupu reformy vstřícný požadavkům církevních hodnostár̆ù ${ }^{58}$ Kritické hlasy slovenských biskupů byly v obecné rovině podpořeny papežskou kurií, která po čsl. straně rovněž žádala urychlenou likvidaci vnucené správy, respektive navrácení slovenských církevních statků do církevních rukou. ${ }^{59}$

ČSR vnucený sekvestr nezamýšlelo prodlužovat donekonečna. Bylo pro něj ovšem nepř́ipustné, aby v nedořešené situaci majetkového vyrovnání s ostřihomským arcibiskupstvím byly nadále nárokovány, at' už z mad'arské či ze slovenské strany, jakékoli výnosy z majetku v zahraničí: ,Je škodlivé, jestliže dnes udržuji se pouta s Mad'arskem i jen tím, že kapitulní kanovníci někteři dostávají z Mad'arska prostředky poukazované jim na účet výtěžků z kapitulních statků ležicích v Mad'arsku. Jest jistě v zájmu církevní a národní konsolidace na Slovensku, aby podobné majetkové zásahy naprosto prestaly, “ uvedl vrchní odborový rada ministerstva zahraničí Eduard Jelen v listu biskupovi Vojtaššákovi z března 1932. Zdůraznil, že př́islušné státní úřady postrádají ,,plné podpory rozhodujicich cirkevních činiteli̊ na Slovensku " ${ }^{60}$ Neústupné pozice slovenských biskupů v čele se spišským biskupem podporoval do značné míry Svatý stolec. Jako nejvíce zainteresovaného a zároveň angažovaného hodnostáře ve sporech s Ostřihomí formálně jmenoval vatikánský státní sekretariát v červnu 1931 Msgr. Vojtaššáka zmocněncem k jednáním o provedení pozemkové reformy a o likvidaci vnucené správy. ${ }^{61}$ Tato volba byla logická a praktická. Spišskému biskupovi nicméně zvýšila sebevědomí před československými úřady, nebot' stvrzovala důvěru a uznání, jakým se v tomto období těšil v ř́mské kurii.

Stanoviska československé diplomacie byla ovšem jasná a musela mít oporu v mezinárodním právu. Chtěl-li stát zachovat a chránit slovenské církevní statky, které byly dříve spravovány ostřihomskou arcidiecézí, byl podle zásady teritoriality povinen ponechat slovenské majetky ležící za hranicemi mad'arským ordinářům. Ušlé zisky měly slovenské straně do budoucna kompenzovat přiměřené náhrady z dotační masy vytvořené souhrnně z vlastnictví všech slovenských diecézí. Vzhledem k velkým majetkovým rozdílům mezi biskupstvími se však vzájemná jednání vlekla. Episkopát vinil z prodlev státní úřady, jež celou zále-

Jelena vyslanci V. Radimskému, 22. 12. 1931.

58 Tamtéž.

59 S. RR. SS., f. AA. EE. SS., fasc 106, pos 97 (3), Nota della Segreteria di Stato, 11. 6. 1931, ff. $62-67 \mathrm{r}$.

60 ANM, f. E. Jelen, k. 1, Dopis E. Jelena J. Vojtaššákovi, přesné datum, bohužel, neuvedeno.

61 AMZV, fond Zastupitelský úřad, k. 7, Francouzská nóta Státního sekretariátu Svatého Stolce č. $1571 / 31$ z 6. června 1931. Italsky viz pozn. Č.58. 
žitost vnímaly přesně naopak a hledaly oporu u pražského nuncia a také přímo ve Vatikánu.

Svatému stolci byly ovšem pravidelně adresovány podobně naléhavé stížnosti mad’arských ordinářů, $\mathrm{v}$ čele $\mathrm{s}$ ostřihomským arcibiskupem Jusztiniánem Györgym Serédim. Ten trval na stanovisku, že čs. vláda doposud neposkytla adekvátní peněžitou kompenzaci za ušlé jmění některých mad’arských církevních subjektů. V několika konkrétních sporech vznesli ostřihomský arcibiskup, ústřední budapešt'ský a ostřihomský seminář a konečně ostřihomská kapitula žaloby před smíšeným rozhodčím československo-mad’arským soudem v Haagu. V dané situaci se též P. Ciriaci ocitl pod náporem argumentací obou stran, jak o tom svědčí jeho dopis kardinálovi Eugeniovi Pacellimu. Státnímu sekretáři se v něm snažil vysvětlit, že záležitost majetkových vyrovnání v podstatě vyžaduje ,oběti z obou stran“, což ani jedna z nich nechce pochopit a setrvává na neústupných postojích. ${ }^{62}$

Spišský biskup coby předseda církevní správní komise byl ovšem v otázce sporného církevního majetku stále netrpělivější. V roce 1932 bylo zřejmé, že se již jednoznačně staví do otevřeného konfliktu se státními úřady. Msgr. Vojtaššák si byl v podstatě jist, že jej v jeho odvážných krocích podpoří slovenští katolíci i kněží. Spoléhal na výklad práva i tradiční oddanost věřících. Byl přesvědčen, že zájmy své diecéze obhajuje obětavě, nezištně, tudíž oprávněně, a doufal, že své stanovisko nakonec prosadí a bude vyslyšen nunciem i státním sekretářem E. Pacellim. Přestože byl později opakovaně obviněn z majetkových machinací, ${ }^{63}$ nehodlal si obdobná nařčení vůbec připouštět ani o nich polemizovat. Jeho postoj vůči čs. vládě odrážel jistě i situaci národnostního složení Spišské župy, respektive obavy z místní, jen slabé převahy slovenského etnika. Vojtaššák se proto odhodlal vstoupit do vysoké politické hry, k čemuž jej částečně přivedla radikalizující se politická situace na východním Slovensku.

Mnozí přívrženci HSLS se zde snažili slovenské věřící vybičovat do protivládní opozice a obhajovali za tímto účelem i spolupráci s mad’arskými a německými menšinami. Pokud to vyžadovala naléhavost situace, bylo třeba jednat všemi možnými, i politickými prostředky. S vědomím autority svého vysokého úřadu se tak spišský biskup cítil výsostně oprávněn rozhodovat o interních záležitostech své diecéze. Zároveň byl přesvědčený, že je zodpovědný za blaho celé slovenské katolické církve. V tomto nalezl podporu u slovenského politického katolicismu a především u některých dalších církevních hodnostárư. Centrální orgány republiky tak byly stále méně úspěšné $\mathrm{v}$ úsilí prosazovat $\mathrm{u}$ těchto duchov-

62 S. RR. SS., f. AA. EE. SS., Cecoslovacchia IV, fasc. 38, pos. 42, List P. Ciriaciho E. Pacellimu, 21.7. 1931, ff. 40r-41r.

63 HROMJÁK, ref. 17, s. 152, 186-188. 
ních morální povinnost loajality, kterou v počátcích republiky nadějně vyzdvihovali mnozí politici. ${ }^{64}$

Spišský biskup se tedy rozhodl do nedořešené otázky majetkových vyrovnání s mad'arskou stranou zasáhnout osobně a rozhodně. Připomeňme, že vláda zamítla žádost slovenského episkopátu na zaplacení dluhů, jimiž byly zatíženy jejich církevní statky, a nepozastavila provádění pozemkové reformy. Situace se dlouhé měsíce nikam neposouvala. Na sklonku roku 1932 tak Msgr. Vojtaššák společně s M. Bubničem a představiteli spišské, banskobystrické a košické kapituly vstoupil do tajných jednání prímo s Ostřihomí. ${ }^{65}$ Pokusil se dosáhnout bilaterální smlouvy s kardinálem Serédim o vzájemných náhradách výtěžků sekvestrovaných majetků. Tento krok ovšem neunikl pozornosti ministerstva zahraničí. ${ }^{66}$ Vojtaššákův postup v této věci ostře odsoudil vyslanec K. Krofta. Návštěvu zhodnotil jako porušení II. článku modu vivendi a nerespektování role pražského nuncia coby prostředníka československo-vatikánských jednání. ${ }^{67}$

Ostřihomská schůzka, jež nakonec nevedla k žádné konkrétní finální dohodě, se odehrála nejen bez vědomí ministerstva zahraničí, ale také bez vědomí pražského nuncia, jenž byl tímto postupem značně dotčen. Vojtaššák měl následně římské kurii sdělit svoje požadavky údajně přímo prostřednictvím kardinála Serédiho. Podle P. Ciriaciho obvinil spišský biskup čs. vládu, že , se církevních statků zmocnila neprávem a mluvil tak, jako by vláda je ani nechtěla církvi vrátit “ ${ }^{68} \mathrm{~V}$ jiném rozhovoru nuncius uvedl: „Nejen mocní cizinci à la Serédi, ale i domácí (Vojtaššák, Bubnič a jiní čs. duchovni hodnostáři) našeptávaji bez ustáni kurii varovně, že čs. vláda schválně protahuje jednání za tím účelem, aby nakonec veškeré cirkevni statky pro sebe podržela. "69

Korespondence mezi Ostřihomí a vatikánským státním sekretariátem potvrzuje, že mezi spišským biskupem a mad’arským primasem existovala skuteč-

64 Např́iklad ministr s plnou mocí pro správu Slovenska Martin Mičura napsal u př́ležitosti nitranského svěcení tří slovenských biskupů v únoru 1921 ve Slovenském denníku, že se církevní politiky na Slovensku chopili „zodpovědni činitelé [...], kteři svojí loajálností, politickým rozhledem a osviceností zaručují nám střizlivé a klidné rešeni otázek církevnè-státnich". LETZ, ref. 17, s. 64.

65 Před dokončením textu se, bohužel, v českých ani vatikánských archivech nepodařilo najít dokument, který by přesněji určil datum této schůzky.

66 ANM, f. E. Jelen k. 1., Zpráva ministerstva zahraničí týkající se rozmluvy K. Krofty s biskupem Vojtaššákem o jeho jednáních s ostřihomským arcibiskupem, 9. 1. 1933.

67 „,Takovýmto jednáním biskup Vojtaššák [...] jednak nerespektuje platnou dohodu s Vatikánem a pokouši se jednati přimo proti ní, což nemůže být lhostejno nejen nám, ježto je to proti naši linii globálního ujednání v rámci Modu vivendi, ale ani Vatikánu, poněvadž se zde zejména nerespektuji plné moci nunciovy. “ Tamtéž.

68 ANM, f. E. Jelen, k. 1, Zpráva vyslance V. Radimského K. Kroftovi, 4. 10. 1932.

69 ANM, f. E. Jelen, k. 1, Zpráva vyslance V. Radimského E. Jelenovi, 31. 12. 1932. 
ně nemalá ochota $\mathrm{k}$ vzájemné dohodě. Společná vyjednávání byla jednoznačně namířena proti stanoviskům československé vlády a nebyla prosta kritiky vůči apoštolskému nunciovi Ciriacimu. ${ }^{70}$

Zákulisní vyjednávání dvou slovenských biskupů v Mad’arsku ministerstvo zahraničí jednoznačně posuzovalo jako závažný a nebezpečný postup, který ohrožuje nejen jednání o církevní majetek, ale samotnou integritu státu. Ústřední vládní představitelé přesto nezašli tak daleko, aby dotčené hodnostáře obvinili podobně jako člena pravicového křídla HSLS Vojtěcha Tuku z vlastizrady. ${ }^{71}$ Neodvážili se stíhat papežovy př́mé apoštolské zástupce. Ve třicátých letech navíc Československo více než kdy dř́ve potřebovalo působit konsolidovaně a nechtělo odhalovat jakékoli vnitřní odstředivé síly, které by ho ohrožovaly. V říjnu 1932 uzavřela totiž l'udová strana politickou dohodu se Slovenskou národní stranou a obě vytvořily jednotný autonomistický blok. Toto uskupení si na trenčínském sjezdu na sklonku prosince 1932 stanovilo společný program, jehož základem byl požadavek vytvoření samostatného slovenského sněmu se zákonodárnou mocí zvláště v otázkách kulturních, administrativních, soudních, hospodářských a sociálních. ${ }^{72}$ Do čela HSLSS se dostávala mladá generace slovenské katolické inteligence. Vládní kruhy si tak zřetelně uvědomovaly, že v českém i slovenském katolickém prostředí opět narůstají kritické hlasy, které vystupují stále otevřeněji protivládně ${ }^{73}$ Nediplomatický krok části slovenské vysoké církevní hierarchie $\mathrm{v}$ čele $\mathrm{s}$ Vojtaššákem silně znepokojil a rozladil ministra Edvarda Beneše, který byl v celém procesu vyjednávání modu vivendi od počátku osobně angažován. Bez nadsázky lze konstatovat, že Beneš tuto dohodu považoval částečně za svůj vlastní úspěch.

O zákulisních jednáních Vojtaššáka a Bubniče v Ostřihomi se díky provládnímu tisku dozvěděla široká veřejnost. Cestu biskupů do Mad’arska komentovalo Národní osvobozeni (24. 12. 1932), Československá republika (3. 1. 1933) či Slovenský denník (31. 12. 1932). Text redaktora Rastlislava Korčáka v něm odsuzoval rozvracečské chování obou slovenských hodnostárư. Napsal o nich mimo

70 Kardinál Serédi si např. v listu z 24. dubna 1933 stěžoval E. Paacellimu, že navzdory faktu, že jednání s Msgr. Vojtaššákem se ukazují jako schůdná a vedoucí k dohodě, pražský nuncius jedná v intencích československé vlády, jež mad’arské církvi odepírají její práva. Žádal proto Pacelliho, aby ve státním sekretariátu působil v zájmu ostřihomské arcidiecéze. S. RR. SS., f. AA. EE. SS., Cecoslovacchia, fasc. 101, pos. 97, f. 22-23.

71 V roce 1929 byl V. Tuka odsouzen k patnácti letům žaláře za špionáž ve prospěch Mad’arska a veřejné vystupování proti československé vládě s pokusem vyvolat odtržení Slovenska v tzv. kauze o vacuum iuris. Více např. BARTLOVÁ, ref. 1, s. 85-89.

72 RYCHLÍK, Jan. Češi a Slováci ve 20. století: 1. díl Československé vztahy 1914-1945. Bratislava: Academic Electronic Press; Praha: Ústav T. G. M., 1997, s. 260. ISBN 8088880106.

73 ŠEBEK, Jaroslav. Za Boha, národ, pořádek. Praha: Academia, 2016, s. 103-109. ISBN 9788020025760 . 
jiné, že jsou oproti svým mad’arským protějškům , s väčšimi vyjednávacími skúsenost'ami a rafinovanou spoločenskou kultúrou" nedostatečně vybaveni a neměli se proto do podobných pokusů pouštět. Československý stát se „,celkom ináč môže opret' mad'arským nárokom v rámci modu vivendi, zjednaným priamo s Vatikánom, a s účinnou legitimáciou správy cirkevných majetkov v ruke ". ${ }^{74}$ Na tuto tiskovou kampaň vládních deníků urychleně zareagoval l’udácký Slovák sérií hned několika článků: ,,Ak aj urobili [Vojtaššák a Bubnič] zákrok v Mad’arsku, urobili ho v zaujme cirkevnom a slovenskom, nasledovne aj štátnom. [Deník] Slovák, ktorý si považuje za povinnost' hájit' čest’ a dobré meno svojich cirkevných hodnostárov, ustaluje, že práve tí dvaja nepotrebujú od toho pokrokárského žurnálu legitimácie, čo do vlasteneckých citov a postupu v čisto cirkevných, hoci majetkových veciach. "75 Navazující text Slováka z 3. ledna 1933 označil modus vivendi za nedochůdče, tuberkulózní, chudokrevné dítě a obvinil ministerstvo zahraničí z toho, že vinu vleklých a nikam neústících jednání týkajících se sporu o ostřihomské církevní majetky svádí nespravedlivě na Mad’arsko. „,Za čtyři roky jsme se nepohnuli kupredu, " tvrdilo se v článku z následujícího dne, který osočil Prahu z toho, že ve svých požadavcích na Svatý stolec přesahuje své pravomoci, které přináleží pouze a jedině katolické církvi a jejím hodnostářům. Článek dále nepokrytě hlásil, že Mad'aři si dotčené církevní majetky a výtěžky z nich nárokují právem a spravedlivě. Vládu označil za jedinou zodpovědnou za zadlužení slovenských diecézí. Měla by tudíž provést nejjednodušší delimitační a dotační plán a smířit se s tím, že se jedná o jmění mad'arských církevních beneficiátů.

Tyto výroky představovaly zřetelné protivládní vyjádření. Otevřeně vstřícný postoj samotného předsedy l’udáků vůči mad'arské církevní hierarchii a jejich nárokům přitom souvisel s již několik let trvající politickou orientací HSL'S. Od parlamentních voleb v roce 1925 se počet jejích voličů začal rozrůstat rovněž o nezanedbatelně velkou skupinu mad'arských či promad'arských stoupenců žijících na Slovensku, kteří v té době nebyli uspokojeni svým druhořadým postavením ve veřejném životě (ve školství, ve státní správě a ve státních podnicích jako např. na železnici) ${ }^{76}$ Hlinka tento fakt toleroval s tím, že každý hlas je potřebný, pokud se má strana u voličstva prosadit. V letech hospodářské krize tak slovenský autonomismus mimo jiné též za pomoci myšlenky „,praobyvatel Slovenska“, akceptoval ve svých řadách slovenské Mad'ary a Němce a zastával se jejich práv s jasným cílem společné opozice proti české politické scéně.

74 ANM, f. E. Jelen, k. 1., výstřižek „K zákulisnému jednaniu slovenských a mad’arských biskupov v Mad'arsku“. In Slovenský denník, 31. 12. 1932.

75 „Slovo k cirkevno-politickej otázke na Slovensku v spojení s „modus vivendi“. In Slovák, 3. 1. 1933, ročník XV., č. 2, s. 3.

76 BARTLOVÁ, ref.1, s. 76; BLÁHOVÁ, Marie - FROLÍK, Jan - KLIMEK, Antonín. Velké dějiny zemí koruny české: 1929-1938. Praha: Paseka, 2002, s. 186. ISBN 8071854255. 
Navzdory výše citované, poměrně bouřlivé tiskové kampani obou dotčených stran na počátku roku 1933 a navzdory prohlubující se hospodářské krizi se jednání o majetkové vyrovnání s Mad’arskem v následujících šesti měsících nikam výrazně neposunula. Svůj podíl na tom tentokrát nesla i aféra spojená s nunciem Ciriacim. Ten musel v ř́ijnu 1933 opustit Prahu v důsledku aféry, která propukla po Pribinových slavnostech uspořádaných v srpnu 1933 v Nitře. ${ }^{77}$ Pražský nuncius dotčen ostrými útoky agrárnického Venkova na svou osobu i Svatý stolec, začal totiž v září 1933 znenadání pět chválu na A. Hlinku. Za hluboké sympatie vyjádřené ve Slováku Hlinkovi a slovenským katolíkům byl na žádost ministerstvo zahraničí vypovězen z ČSR. ${ }^{78}$ Pokračování jednání o modus vivendi bylo tak na nějaký čas ochromeno. Vládní delimitační komise k 24. prosinci 1933 nicméně vyhotovila sanační plán, jenž měl posloužit k vyrovnání pasiv slovenských církevních majetků vzniklých za dobu vnucené správy. Komise ovšem neuznala oprávněnost požadavku vydání statků biskupstvím bez dluhů a břemen a také nehodlala upustit od pozemkové reformy.

Reakcí na tuto situaci bylo druhé samostatné vyjednávání Msgr. Vojtaššáka (bez pověření vlády) s kardinálem J. Serédim v červenci 1934. ${ }^{79}$ Spišský biskup v Ostřihomi dle vlastních slov uzavřel jakousi oboustrannou smlouvu ustanovující „spravedlivé“ rozdělení katolických majetků mezi církevními beneficiáty na Slovensku a v Mad'arsku, kterou jako jedinému kompetentnímu fóru předložil Vatikánu. ${ }^{80}$ Rozladěnému ministerstvu zahraničí, které bylo o jeho postupu opět informováno, biskup navíc sebevědomě vzkázal: ,, Ustalujem tu len to, že až by bol môj projekt i Sv. Stolicou prijatý, postavil som zlatý most našej vláde, eminentne nášmu ministerstvu zahraničia ku konečnému zriadeniu cirkevno-politických vecí na Slovensku. "81

Jako už dř́ve v minulosti, spišský biskup překročil své pravomoci a nerespektoval samotnou podstatu modu vivendi, který stipuloval proces př́mých jednání jen mezi Svatým stolcem a Československem. Vojtaššák nadto Svatému stolci adresoval obvinění osočující čs. ministerstva a jejich orgány z toho, že dočasná správa slovenských církevních majetků způsobila nenahraditelné škody a nemá

77 Nitranský biskup Marián Blaha se musel na nátlak pražské vlády vzdát předsednictví organizačního výboru nitranských slavností, jehož byl na základě pastoračního listu z 15. února 1933 pověřen ostatními slovenskými biskupy.

78 ŠMÍD, Marek. Pietro Ciriaci. Neúspěch v Československu klíčem k jeho dalšímu vzestupu? In Historia Olomucensia 44/2013, s. 35-73. ISSN 1803-9561; HRABOVEC, Emília. Pribinove slávnosti v Nitre a vypovedanie nuncia Ciriaicho z Česko-Slovenska 1933. In Studia historica Tyrnaviensia, 2004, s. 73-96. ISBN 8080820074.

79 S. RR. SS., f. AA. EE. SS., Cecoslovacchia, fasc. 120, pos. 97, ff. 6r-13r. Seznam všech nárokovaných majetků slovenských diecézí v Mad’arsku odeslaný J. Vojtaššákem E. Pacellimu, 20. 7. 1934.

80 ANM, f. E. Jelen, k. 1., Dopis J. Vojtaššáka K. Kroftovi, 25. 9. 1934.

81 Tamtéž. 
uspokojivých výsledků. ${ }^{82}$ Kroftovi a Benešovi tehdy již opravdu docházela trpělivost. ${ }^{83}$ Situace se stávala závažnou. Pokud by Vatikán těmto kritickým hlasům uvěřil, byla by nejspíš opět na dlouhou dobu zvrácena ochota Státního sekretariátu Svatého stolce přistoupit k urychlenému podpisu dohody o vnější delimitaci diecézních hranic, tím spíše, že vzájemnou komunikaci mezi Prahou a Římem $\mathrm{v}$ předchozích měsících zaměstnávala otázka vyrovnání s vratislavskou arcidiecézí. (K definitivnímu ustanovení hranic vratislavského arcibiskupství došlo nicméně až v 70. letech.) Vláda urgentně potřebovala dořešit dotační otázku slovenských biskupství, aby byla zastavena další kritika týkající se špatného hospodaření vnucené správy na slovenských církevních statcích. Ministerstvo zahraničí zároveň doufalo, že požadavky mad’arských církevních jednotek nebudou řešeny mimocírkevní cestou před smíšeným rozhodčím soudem v Haagu.

Tentokrát ovšem Ján Vojtaššák rozehrál př́liš vysokou hru. Ve snaze urychleně docílit rozdělení sporného ostřihomského majetku, a zároveň donutit vládu k definitivnímu ukončení vnuceného sekvestru, svolil k významným ústupkům mad'arské straně. ${ }^{84}$ Adekvátní reakce na sebe nedala dlouho čekat. Téměř všichni slovenští biskupové kromě M. Bubniče, tedy P. Jantausch, M. Blaha, K. Kmet'ko, P. Gojdič a J. Čársky podali 9. srpna 1934 protest ke Svatému stolci vůči řešení, které J. Vojtaššák navrhl Vatikánu jako východisko majetkového vyrovnání s Mad'arskem. Obvinili jej z př́lišné vstřícnosti vůči J. Serédimu, konkrétně z toho, že dovolil, aby $75 \%$ všech sporných církevních majetků patřilo Mad'arsku a jen $25 \%$ Slovensku. ${ }^{85}$

Představený spišské diecéze zklamal důvěru ostatních slovenských biskupů. Jejich protestní list do Vatikánu lze interpretovat jako roztrpčení nad výsledkem Vojtaššákových jednání spíše nežli jako náhlý projev loajality k čs. státu. Vojtaššákova dohoda se Serédim totiž paušálně znevýhodňovala benefiční majetek všech slovenských diecézí. Biskupové pravděpodobně pojali osobní podezření, že spišský biskup jednal s úmyslem zvýhodnit své vlastní biskupství. ${ }^{86}$ Vojtaššák

82 ANM, f. E. Jelen, k. 1, český překlad Dopisu K. Krofty kardinálu E. Pacellimu, 2. 11. 1934.

83 AMZV, f. Politické zprávy Vatikán, r. 1934, Rkp. dopisu K. Krofty B. Messánymu, 19. 9. 1934: , Pouze k Vaší osobni informaci, komplikace nastala tím, že Vojtaššák se dohodl za zády vlády se Serédim o rozdělení slovenských církevnich statků na basi pro nás naprosto nepřijatelné. Šetření o této věci je v plném proudu. Zatím se v rozmluvě s kardinálem [Pacellim] nevyjadrujte príliš pesimisticky. "

84 CSÍKY, Balázs. Az első bécsi döntés hatása az Esztergomi Főegyházmegyére 1938-1945. In Magyar Egyháztörténeti Vázlatok, 2012, Vol. 24, No 3-4, s. 79-103, zde s. 81.

85 S. RR. SS., f. AA. EE. SS., Cecoslovacchia, fasc. 120, pos. 97, ff. 24r-28r.

86 V té době již prosakovaly na veřejnost podezření, že dřívější hospodaření biskupa v jeho diecézi vedla $\mathrm{k}$ jeho osobnímu obohacení. Podezřelá byla v roce 1932 například suma 3325000 Kč, jíž biskup z vlastních zdrojů přispěl na kompletní přestavbu kněžského semináře spišské diecéze. HROMJÁK, ref. 18, s. 154. 
se těmto obviněním bránil dopisem do Vatikánu z 15. října $1934 .{ }^{87}$ Vinil v něm československou vládu, že nese vinu na neřešení problému snížení dluhů slovenských církevních statků. Váhavá reakce kurie jej nakonec přiměla zastavit činnost církevně-správní komise, jíž byl předsedou a stáhnout svá ostrá obvinění vưči vládě.

Svatý stolec se ve skutečnosti tehdy nalézal pod paralelní salvou mad’arských i československých žádostí a stížností, jimiž se obě zúčastněné strany navzájem osočovaly. Někteří vatikánští hodnostáři dopřávali kredit Vojtaššákovu obvinění, že ČSR se všemocně brání odevzdání církevních statků do správy církve. Sekretář kongregace pro mimořádné církevní záležitosti Giuseppe Pizzardo např́íklad otevřeně doznal, že jsou mu návrhy biskupa Vojtaššáka kardinálu Serédimu známy. Prohlásil ovšem, že Svatý stolec není zodpovědný za chování jednotlivců. Tvrdil, že takovéto jednání nemá prý na Vatikán vliv ${ }^{88}$ Kurie se každopádně ve svých výrocích ohledně státní správy slovenských církevních statků na sklonku roku 1934 vyjadřovala velmi nepř́znivě. Ministerstvo zahraničí se proti podobným nařčením rozhodně ohrazovalo. Jeho pozici však komplikovala účinná mad’arská propaganda šírící ve Vatikánu obvinění o přetrvávajícím špatném vztahu ČSR ke katolické církvi a její hierarchii. ${ }^{89} \mathrm{Na}$ počátku 30 . let bylo přitom Mad’arsko Vatikánem nadále vnímáno pozitivně jako významný sloup katolicismu ve střední Evropě. Primas Serédi si v římské kurii uchovával velký vliv díky osobnímu prátelskému vztahu s papežem Piem XI., který jej pokládal za znalce církevního práva $\mathrm{v}$ otázce mezinárodních vztahů. Také poměr mad’arské vlády ke Svatému stolci byl v té době velice srdečný, podobně jako poměr kurie k ministerskému předsedovi Guyulovi Gömbösovi. ${ }^{90}$

I tyto okolnosti přispěly $\mathrm{k}$ tomu, že taktika spišského biskupa do značné míry přeci jen přinesla své ovoce. Není nejspíš př́liš odvážné uzavř́t Vojtaššákova zákulisní jednání tímto hodnocením. Konečný rozsah a způsob provádění pozemkové reformy byl sjednán mezi vládní stranou a církví nakonec v součinnosti se spišským biskupem (generální dohoda o statcích tvořících dotační masu). Posouzení vzájemných nároků československých a mad’arských církevních jed-

87 S. RR. SS., f. AA. EE. SS., Cecoslovacchia, 1934, pos. 97 P. O., fasc. 120, ff. 35r.-36r.

88 Zároveň ale prohlásil: „Odevzdejte ihned statky, které držite již 16 let. Nevěřim, že je odevzdáte, vždyt' se o to pokoušeli již tři nunciové. “AMZV, f., ZÚ k. 7, Zpráva Radimského na ministerstvo zahraničí týkající se jeho rozhovoru s G. Pizzardem, 19. 10. 1934.

89 Teprve na konci června 1934 byl formálně definitivně vyřízen incident vypovězení nuncia Ciriaciho výměnou oficiálních omluvných listů mezi ministrem Benešem a sekretářem Pacellim na jedné straně a nunciem a Benešem na straně druhé. Vatikán si na čs. vládě nadto vyžádal oficiální vyjádření politování nad urážkami, kterých se čs. tisk dopustil proti papeži. AMZV, f. Politické zprávy Vatikán 1934, II. periodická zpráva II. čtvrtletí, 11. 7. 1934.

90 AMZV, f., PZ Vatikán 1934, Politická zpráva čtvrtletní, 8. 4.1934. 
notek na sporný ostřihomský majetek se s konečnou platností ujal Svatý stolec, respektive dikasterium ř́mské kurie. ${ }^{91}$

Dne 14. května 1935 uzavřela ČSR s Vatikánem Dohodu o postupu provádění a naplňování modu vivendi (č. 1. 576/35). Ve třetím článku se čs. vláda zavázala, že slovenské církevní statky vydá do rukou církevního správce. Již v prosinci 1934 doporučilo ministerstvo zahraničí za nejvhodnější kandidáty na toto místo trnavského administrátora Pavla Jantausche či královéhradeckého biskupa Mořice Píchu..$^{92}$ Dne 1. června 1935 převzal Msgr. Jantausch designovaný Svatým stolcem od státní administrativy slovenské církevní statky a byl pověřen, aby po dobu čtyř měsíců dohlížel na revizi dosavadního hospodaření těchto subjektů. Tímto byla Československá správní komise a společně s ní i likvidační komise zrušena.

Volbu P. Jantausche za správce církevních statků vláda pojala jako jistou garanci budoucí vstřícnosti $\mathrm{v}$ jednáních se slovenskými hodnostáŕi. Ministerstvo zahraničí nemohlo dále tolerovat spišského biskupa v čele jakékoli správní komise dohlížející nad slovenským církevním majetkem. Naopak Jantausch se v předchozích krizových letech ukázal jako ochotný se s vládou dohodnout. Námitky, které měla republika $\mathrm{v}$ roce 1922 proti jeho nominaci do čela jednoho ze slovenských biskupství, byly za současné situace zapomenuty.

Msgr. Pavel Jantausch se před převratem i po něm angažoval národně, pomáhal zakládat slovenské národní rady a jako okresní předseda SL'S v Topolčanech aktivně hájil práva Slováků. ${ }^{93}$ Po svém jmenování trnavským administrátorem však svou dřivější stranickou aktivitu do značné míry omezil. V porovnání s jinými slovenskými hodnostáři rozuměl zřejmě více potřebě vzájemné spolupráce a kompromisu se státní stranou ve složité otázce majetkových vyrovnání. Sám se ostatně po léta aktivně účastnil správy slovenských statků.

Vláda mohla také ocenit jeho dlouholeté úsilí zvrátit skepsi Svatého stolce v oprávněnosti zř́zení bratislavské teologické fakulty, která vznikla nicméně až po dlouhých průtazích v roce 1936. Trnavský biskup rovněž projevil vstřícnost ke kompromisu s vládou v otázce postátňování církevních škol na Slovensku. V létě 1935 tak byla Msgr. Jantauschovi svěřena nesnadná úloha stát se diplomatickým urovnávačem rozdílných zájmů mezi státem a slovenským episkopálním sborem.

Současně s nástupem nového pražského nuncia Saverio Rittera v říjnu 1935 do funkce tak prakticky nastala další éra diplomatických styků ČSR s Vatiká-

91 AMZV, f. ZÚ 9, Srov. Dopis Ministerstva zahraničí státnímu sekretáři E. Pacelllimu, 11. 6. 1935.

92 ANM, f. E. Jelen k. 1., List V. Kožíška E. Jelenovi shrnující Benešovo rokování s Luigim Punzolou, 3. 12. 1934.

93 BOSÁK, Lubomír - KÝŠKA, Patrik (ed.). Velký duchom: dr. Pavol Jantausch, biskup, prvý apoštolský administrátor trnavský. Vrbové 2010, s. 11-13. ISBN 9788097040635. 
nem. Navzdory původnímu př́slibu kurie z května 1935 nedošlo nicméně k odvolání mad'arských žalob u soudu v Haagu. Československo se tohoto požadavku nakonec vzdalo. ${ }^{94} \mathrm{Z}$ prezidentských voleb v prosinci 1935 vzešel jako vítěz E. Beneš. Jisté zásluhy na tom měl i nuncius Ritter, kterému se podařilo v Benešův prospěch přemluvit A. Hlinku a umírněnějšś část jeho strany.

Celková politická situace $\mathrm{v}$ republice se však již zřetelně vyvíjela jiným směrem. Národnostní menšiny a jejich mluvčí, včetně církevních, se ozývali vůči české politické veřejnosti a jejím špičkám stále kritičtěji. Požadavek administrativní a kulturní autonomie Slovenska byl prezentován stále častěji a hlučněji. Nejinak tomu bylo na oslavě Hlinkových sedmdesátin koncem září 1934 v Ružomberoku. Došlo zde k politické manifestaci, před jejímž zahájením celebroval Hlinkův vytrvalý spolupracovník, spišský biskup, polní mši. ${ }^{95}$

Na politickém fóru gradovaly výtky kritizující vládu za předchozí špatné hospodaření se slovenským církevním majetkem a neschopnost definitivního naplnění dohody o modu vivendi. Karol Sidor, Josef Tiso, Andrej Hlinka, Martin Rázus a několik dalších slovenských poslanců ve své parlamentní interpelaci z 21. ledna 1937 pak obvinili vládu, že v roce 1919 dala církevní majetky na Slovensku úmyslně do záboru, aby byl slovenský katolicismus hospodářsky oslaben a ochromila se tak jeho celková vitalita. ${ }^{96}$

Toto výše uvedené stanovisko ostře kritizující československé vládní kruhy podporovala ovšem jen část slovenské vysoké církevní hierarchie. Naopak, Msgr. Jantausch př́islušným ministerským úřadům dodal ve všech ohledech pochvalně znějící revizní protokoly o převzetí církevního vlastnictví a snažil se o svém závěru přesvědčit nuncia Rittera a římskou kurii. Někteří slovenští biskupové však byli ve druhé polovině 30 . let do jisté míry ovlivněni propagandistickou kampaní autonomistického bloku, který obviňoval ČSR z př́lišné náklonosti k SSSR. ${ }^{97}$ Tyto domněnky je znepokojovaly. Na rozdíl od agitace slovenského kněze, politika a agenta Františka Jehličky u Svatého stolce ${ }^{98}$ však k otevřeným

94 Vatikán totiž $\mathrm{v}$ průběhu jednání přišel s novým požadavkem - bud' dojde ke schválení modu vivendi $\mathrm{v}$ ČSR parlamentní cestou, nebo bude Vatikán zproštěn závazku přimět mad’arskou stranu k odvolání žalob podaných v Haagu. Pro Československo však tato podmínka nebyla přípustná. AMZV, Praha, fond PZ Vatikán: 1936, periodická zpráva č. 3.

95 BARTLOVÁ, ref. 1, s. 96.

96 Poslanecká sněmovna NS RČS 1935-1937, PS 1937, Tisk 771/I. Interpelácia poslanca Karola Sidora vláde vo veci rímsko-katolíckych církevních majetkov, nachádzajúcich sa pod zátvorom. http://www.psp.cz/eknih/1935ns/ps/tisky/t0771_01.htm.

97 Srov. Interpelaci slovenských poslanců, bod 2: „,Tendenčnost', nedemokratickost' ba priamo protikatolícka zaujatost' tohoto neupraveného vzt'ahu [ČSR a Svatého stolce] bije tým viac do oči, ked' uvážime ochotu, s akou sa siahlo $k$ vytvoreniu nielen dobrého, ale priamo intímneho pomeru so SSSR, s týmto zásadným nepriatel’om každého pokroku, civilizácie a všetkých základov, na ktorých dnešná spoločnost'spočiva. "Tamtéž.

98 Jehlička v kuriálních kruzích rozšiřoval například lživou informaci o tom, že ČSR na svém 
výpadům proti ČSR nepřistoupili. Oproti tomu Ján Vojtaššák zůstal nejradikálnějším a nejreakčnějším ze slovenských ordinářů navzdory koncesím, které ČSR vůči slovenské církvi akceptovalo.

Apoštolští administrátoři jmenovaní po vzniku ČSR byli zajisté starostlivými biskupy, kteří napomáhali duchovnímu a kulturnímu rozvoji slovenské společnosti. Zároveň se cítili povinni š́řit a podporovat v ní svébytné kulturní a duchovní hodnoty. V počátcích republiky přesto veřejnosti vštěpovali státoprávní vědomí a myšlenku užitečnosti sounáležitosti $\mathrm{k}$ novému státu, jenž měl slovenské věrící zbavit mad'arského područí. Garantovat hranice nových diecézí tak, aby vyhovovaly národnostně, bylo společným cílem státu i církve. Slovenský episkopát byl však mnohdy nesebekriticky přesvědčen, že pražský byrokratický aparát omezuje hospodářský, a tím i kulturní a sociální vývoj slovenské církve. Léta 1927-1938 tak představovala roky přetrvávající nedůvěry mezi státem a biskupy. Narůstající deloajalitu duchovních, jež byla důsledkem této nedůvěry, lze ovšem vzhledem k trvajícímu antiklerikalismu české politické scény do značné míry chápat jako nevyhnutelnou.

* Článek vznikl v rámci výzkumného projektu GA 16-15083S nesoucí název Éra nuncia Ciriaciho. Československo-vatikánské vztahy 1928-1934.

\section{LOYALITÄTSKONFLIKT. DIE EINSTELLUNGEN DES SLOWAKISCHEN EPISKOPATS IM PROZESS DER KOMPLIZIERTEN UMSETZUNG VON MODUS VIVENDI 1928-1935}

\section{EVA H A J D IN O V Á}

Der Beitrag bedient sich des Konzepts des Loyalitätskonflikts, mit dessen Hilfe die gemeinsamen politischen Verhandlungen über die Umsetzung des Abkommens über Modus Vivendi in den Jahren 1928-1934, die die zentralen tschechoslowakischen politischen Organe mit dem slowakischen Episkopat führten, analysiert werden. In den Verhandlungen engagierte sich selbstverständlich der Heilige Stuhl, der als hoheitliche Autorität bei der abschließenden Entscheidung über die Aufteilung und der Vermögensdotation der slowakischen Erzdiözesen auftrat. Der Tschechoslowakei ging es darum, damit sich die Grenzen der Diözesen mit der Staatsgrenze der Tschechoslowakei überdeckten. Die

území zřizuje letiště pro sovětské vojenské letectvo. Ve svých propagandistických letácích požadoval oddělení Slovenska a Podkarpatské Rusi od Československa, protože tato území, na rozdíl od českých zemí, nechtějí být „,mostem bolševismu do Evropy“. STEHLÍKOVÁ, Michaela. Vztahy Československa s Vatikánem v letech 1935-1938. Bakaláŕská práce FSS Masarykovy univerzity, Brno 2014, s. 28. 
Tschechoslowakei sequestrierte dabei in der unstabilen sozialen, politischen und wirtschaftlichen Nachkriegsklima die slowakischen kirchlichen Besitztümer. Diese Tatsache rief eine immer größer werdende Unzufriedenheit, Skeptizismus und Misstrauen der slowakischen Ordinäre, unter der Führung des Zipser Bischofs Msgr. Ján Vojtaššák, hervor. Nach dem Kriegsende äußerte die slowakisch sprechende Kirchenhierarchie völlige Unterstützung für die tschechoslowakischen Staatsbildende Idee, jedoch seit dem Ende der 20er Jahre kritisierte sie immer schärfer den Staat wegen der unkorrekten und nicht berechtigten Verwaltung der kirchlichen Besitztümer. Bei dieser Kritik fanden die slowakischen Ordinären die Unterstützung unter den führenden Vertreter der Hlinkas slowakischen Volkspartei. Der gegenseitige Konflikt kulminierte im Dezember 1932 und im Juni 1934 durch die geheimen Verhandlungen der Bischöfe J. Vojtaššák und M. Bubnič mit dem Erzbischof von Esztergom Jusztinián Serédi. Angesichts der andauernden revisionistischen Bemühungen Ungarns gegenüber der Tschechoslowakei, gerieten die Bischöfe dadurch in einem eindeutigen Interessenkonflikt und sie verletzten de facto das frühere Loyalitätsprinzip.

Mgr. Eva Hajdinová Ph.D.

Masarykův ústav a Archiv AV ČR, v. v. i.

Gabčíkova 2362/10, 18200 Praha 8

Česká republika

e-mail: hajdinova@mua.cas.cz 